\title{
The changing face of social work: social worker perceptions of a neoliberalising profession.
}

\author{
BUTLER-WARKE, A., YUILL, C. and BOLGER, J.
}

2020

This is a post-peer-review, pre-copy edited version of an article published in Critical and Radical Social Work. The definitive publisher-authenticated version BUTLTER-WARKE, A., YUILL, C. and BOLGER, J. 2020. The changing face of social work: social worker perceptions of a neoliberalising profession. Critical and radical social work [online], $8(1)$, pages $59-75$, is available online at: https://doi.org/10.1332/204986019X15633629305936. 


\section{Introduction}

The year 2019 marks the sesquicentenary of the founding of the Charity Organisation Society (COS) in London in 1869 (Social Work at Edinburgh University, 2018). Along with the University Settlement programme and the social administrative processes of the Poor Law, the COS was an instrumental first step in the establishment of social work as a profession (Lymberry, 2005). Over the ensuing 150 years, social work training programmes emerged at colleges and universities throughout the British Isles and around the world (Social Work at Edinburgh University, 2018), signalling the formalisation of social work education.

This paper takes the 150 year anniversary of the founding of the COS and the 50 year anniversary of the social work training programme at a university in northeast Scotland (henceforth referred to as 'the university') as a pivotal moment in the history of social work and takes the opportunity to reflect on the recent imposition of neoliberalism to the social work profession in Britain. While existing literature reflects on the current state of social work and, particularly, the neoliberal agenda's influence on practice (see for example Ferguson, 2009; Ferguson and Woodward, 2009; Ferguson and Lavalette, 2013; Spolander et al, 2014; Rogowski, 2015), we build our argumentation from in-depth interviews with social work practitioners in Scotland, meaning that we unearth the lived reality of change in social work and use first-hand accounts to build an account of change, neoliberalism and austerity in the late $20^{\text {th }}$ and early $21^{\text {st }}$ centuries, thereby connecting the lived reality of perceived change with the larger structural and systemic vision. Our paper, because of the case study site, is UK-centric but we acknowledge that neoliberalism's reach into social care is not unique to the UK.

Our study serves as a discussion with current theoretical literature. We weave together existing literature with our study's empirical data to give social workers a voice in describing the perceived changes in the field. We begin with a summary of the existing ideas relating to neoliberalism and its political genesis, with reference to particular exemplifying changes and policies, before discussing our methodology. We then use combined findings and discussion sections to interweave the voices of our participants with current debates . Before making concluding comments, we offer a discussion based on our findings connecting the existing literature on neoliberalism and the lived-experiences of social workers reflecting on how this larger politicoeconomic system manifests itself in social work practice. 


\section{Neoliberalism and social work: a review}

Neoliberalism is a feature of the past three decades (Spolander et al., 2014: 302). As Harvey (2016) explains, it is a "political project carried out by the corporate capitalist class as they felt intensely threatened both politically and economically towards the end of the 1960s into the 1970s" in response the perceived threat of radical and counterrevolutionary projects. The shift to a neoliberal society was no accidental transition; it was operationalised by politicians "to reorder the political economy of post-war capitalism-modifying its existing class relations, its organizing structures, and its institutions of accumulation" (O’Conner, 2010: 695).

The central tenet of neoliberalism can be summed up as "the belief that the free market and free trade are best suited to meeting human wellbeing" (Rogowski, 2015: 54). The neoliberal agenda relies on the market as the source of rights and freedoms, and the need for increased privatisation and financialisation. It is associated with "public expenditure cuts, curbing the powers of trade unions and the privatisation of nationalised industries" (Rogowski, 2015: 54). Neoliberalism slashes the safety net of the welfare state and replaces it with a market-centric approach that foregrounds "capital accumulation strategies over social concerns" (Morley et al., 2019: 37).

\section{Thatcherism}

PM Thatcher (1979-1990) is often seen as foundational in the onslaught of neoliberal policies in Britain (Ferguson and Lavalette, 2013: 98; Rogowski, 2015) and, indeed, in the Conservative Party's The Right Approach document, the Party suggests that inequality, poverty and deprivation can be solved through 'market-centrism' (Mudge, 2008), privatisation and profit. The document states:

The main reason why we have not done better in providing for the needy is that our economy has not grown as rapidly as that of other countries, where more successful, more profitable, and less hampered private enterprise systems have produced more resources for improving the real standards of community services" (Conservative Party, 1976: 57)

The influence of neoliberalism on social work can be traced to PM Thatcher, though Thatcher's early years in office actually had little impact on the day-to-day practice of social workers (Rogowski, 2015). The Barclay Report, commissioned in 1980 and presented in 1982, sought to examine the role of the social worker in society and the report called for a community social work 
approach. This was largely ignored by Thatcher's government, except locally in Scotland, where the Social Work (Scotland) Act of 1968 had also seen inroads being made into care provision (Turbett, 2018). In her later years in office, the Thatcher government's actions had significant bearing on the profession. In 1989, it issued the Children's Act, which, social worker Steve Rogowski argues, "involved a change from working therapeutically with children and families to protecting children by means of surveillance and control" (2015: 56). This authoritarian turn matches the advent of authoritarian neoliberalism as described by Bruff (2013: 113), "which is rooted in the reconfiguring of the state into a less democratic entity through constitutional and legal changes that seek to insulate it from social and political conflict"' (2013: 113).

Rogowski (2015)notes that police, lawyers and the courts came to be involved in the inspection of social work actions (2015: 56). This inspection process was aligned with a greater neoliberal shift towards the bureaucratisation of social work as exemplified in the case of the NHS and Community Care Act of 1990. This "resulted in direct, relationship-based work with adult users being replaced by social workers being embroiled in bureaucracy aimed at rationing resources, something that was to eventually affect social work with children and families" (Rogowski, 2015: $56)$.

\section{New Labour and the Third Way}

The application of neoliberalism to social work can be seen even more clearly during the Third Way politics of New Labour (1994-2010) under PM Tony Blair (1997-2007), with the Third Way serving as "an ideological shell for neo-liberalism” (Anderson, 2000: 11 in Ferguson, 2004). Under the Third Way, which was supposed to take the best from both left and right politics (Ferguson, 2004), neoliberal values triumphed as a common-sense acceptance of capitalism thrived, the role of the individual-rather than the collective-rose, creeping privatisation increased, managerialism flourished, and the state's role came to be based on monitoring, metrics and control. Situated as part of this larger neoliberal agenda, poverty and deprivation came to be markers of individual failure. Wealth came to be seen as a marker of individual success, and lack of wealth came to be pathologized as a marker of personal failure for not accruing financial capital.

In his review of the neoliberal policies of the Third Way and their effect on social work, Ferguson (2004) notes that there grew a focus on value for money, which was "led by managers whose primary remit is often to manage budgets rather than to meet the needs of clients, and too often staffed by demoralised practitioners who feel increasingly alienated from their organisations and 
from what now passes as social work" . He similarly notes a privatisation of social work, with "services being transferred to private or voluntary organisations which are cheaper because they are able to offer lower rates of pay and poorer conditions to staff...The overriding priority is keeping costs down, with profound effects on the morale of social workers" (Ferguson, 2004). Finally, he notes that the new outcome-oriented approach and the evidence-based approach rely on "behaviourist approaches which measure behavioural change and which usually have a strongly individualistic focus, with little concern for wider social factors" (Ferguson, 2004).

A further means through which the bureaucratisation of social work practice was made manifest was through New Labour's unveiling of the Framework for the Assessment of Children in Need and their Families in 2001 (Rogowski, 2015). For Garrett (2003), the Framework standardised care provision through the use of rigid, technologised metrics in order to "ration resources at the expense of meeting the need" of children and families (Rogowski, 2015: 58). While the advantage of the Framework lies in its ability to systematically interrogate the needs of the child, its weakness lies in this strength. The Department of Health publication introducing the Framework states that the new procedure "gathers together the essential information about the child including ethnicity, household composition, parental responsibility and agencies currently involved with the child and family" (2000: 1). For Parton (2008 in Rogowski, 2015: 58), this systematised, bureaucratic approach to social work transitions the field "from a concern with the 'social' to the 'informational"', in line with a broader neoliberal New Labour agenda (Garrett, 2003). For Rogowski (2013 in Rogowski, 2015: 59), it is the use of the information gathered as part of the Framework that signals the bureaucratic turn and resultant neoliberalisation of social work as, "after information has been gathered, parents are often simply told to change their behaviour/lifestyle or face the threat of losing their children by adoption to middle-class families; this an example of the aforementioned authoritarian, punitive turn".

\section{Neoliberalism and the Conservative governments}

The changes under the Conservative governments of PM Cameron (2010-2016) and PM May (2016-2019), have continued to wreak hardship and suffering in relation to social work and welfare. PM Cameron unleashed the 'Age of Austerity' whose punitive sanctions have hit hardest the most vulnerable in society and have taken away the safety net on which people rely. These cuts are, according to Levitas (2012: 320), simply the latest part of "a thirty-year process of redistribution to the rich". Conservative cuts are linked closely to the notion of the Big Society, introduced by PM Cameron in 2010. Couched in language of community, voluntarism and citizenship, the Big 
Society builds on Thatcherite and New Labour models of citizenship (Davies, 2012). It diminishes the role of the state in the provision of services and assumes that (untrained) volunteers can bridge the gap left behind. The Big Society has been discussed widely elsewhere (see Ishkanian and Szreter, 2012) but it warrants inclusion here in relation to social work. As Levitas (2012: 322) explains:

Talk of the 'Big Society' is...little more than an attempt to get necessary social labour done for nothing, disproportionately by women, by pushing work back across the market/non-market boundary...We'll axe the programme for intensive social work with families with multiple problems, and replace it with untrained volunteers in the Working Families Everywhere programme, headed up by millionaire Emma Harrison.

The Working Families Everywhere programme is "a pilot project in which unqualified volunteers will enter the homes of 100,000 'problem' families to 'inspire' them into work by their example" (Gold, 2011). According to Levitas (2012), the programme diminishes the role of the social worker, assuming that untrained volunteers can provide the same services. It also adds a moralising dimension whereby 'decent' citizens are meant to enthuse others. This is antithetical to the values of social work in which relationships and processes are foregrounded; the scheme also serves as an example of the way that the Big Society served as a conduit for cuts in services, while simultaneously presenting as supporting aims of community empowerment. With councils being allocated lower budgets-and poorer areas being disproportionately affected by these reduced budgets—care provision has suffered.

Jones (2017) notes that the Conservative Party's attitude towards social work is troubling, and implies both that social workers are overly idealistic and that individuals are responsible for their lot in life. He references the speech made by Secretary of State for Education Michael Gove (20102014) in which Gove states:

In too many cases, social work training involves idealistic students being told that the individuals with whom they will work have been disempowered by society. They will be encouraged to see these individuals as victims of social injustice whose fate is 
overwhelmingly decreed by the economic forces and inherent inequalities which scar our society .

This vision of social work is detrimental both to social workers and to service users. It frames structural issues as having no bearing on the fate of an individual and, rather, that the individual remains responsible for his/her outcome.

\section{Methods}

Noting these vast social, political and economic changes that have affected social work and social workers, it is necessary to assess how social workers perceive these changes. To mark the 50 year anniversary of the implementation of social work programmes at the university, the department wanted to engage with graduates of the university's social work training programmes to ascertain how their careers had progressed, whether they felt that their education and training had prepared them for practice, and, crucially, how they viewed changes to the field of social work since their graduation.

The call for participants was disseminated through social media, local media, alumni networks, and through local councils and voluntary organisations; graduates were asked to contact a member of the research team if they wished to be part of the study. A total of 33 respondents were first sent an eight-question questionnaire that probed their career path, levels of preparedness, aspirations, and reflections on their time in social work. This sample size was deemed to be suitable for the research as the sample included social workers of a variety of ages, academic qualifications and career backgrounds. The sample size roughly correlates or exceeds that employed in similar studies that also follow an exploratory framework (see Barton et al., 2005; Aadnanes 2015; Yuill, 2018). The 33 respondents were asked if they wished to be involved in a more in-depth interview or focus group and, in the weeks following the submission of the questionnaires, a series of 10 interviews and three focus groups were conducted. All respondents were graduates from the same university, having graduated between 1970 and 2013 and had studied for: BA Applied Social Sciences with Diploma, BA Applied Social Science with Certificate in Qualification in Social Work (CQSW), Diploma in Social Work, Diploma in Social Work by Distance Learning, Certificate in Social Work (CSW), PG Diploma in Social Work, CQSW, BA Public Administration with CQSW, BA (Hons) Social Work, BA (Hons) Social Work by Distance Learning, MSc and Diploma in Social Work (DipSW), or BA (Hons) Social Work with DipSW.The interviews were recorded and transcribed. Copies of the transcripts were sent to respondents for their approval before the analysis stage of 
the study. The interviews were thematically analysed following an inductive thematic analysis approach that allowed codes to develop as the research progressed. A second round of coding sorted the initial codes into more inclusive themes that were subsequently examined to note commonalities and differences.

\section{Perceived external changes that impacted on practice}

We divide our findings and discussion according to perceived external changes and perceived internal changes. In interviews, respondents noted imposed external pressures that are largely politico-economic and technological in nature as well as noting changes that occurred within the profession. Section 4 discusses these external changes and uses interview quotations to give firsthand accounts of the perceived changes imposed upon social work in the latter half of the $20^{\text {th }}$ century and early $21^{\text {st }}$ century. Section 5 examines the internal changes.

\section{Poverty and austerity}

The first change noted by participants relates to the perceived increase in poverty and deprivation in society. Poverty and social inequality have increased since the 1980s (Dorling et al. 2007), in line with the implementation of a neoliberal politico-economic agenda. Dorling et al. note that "Britain is moving back towards levels of inequality in wealth and poverty last seen more than 40 years ago". The austerity agenda in Britain that emerged during the Conservative-Liberal Democrat coalition (2010-2015) and continued under the Conservative government (2015present) has only worsened the dire situations in which the most vulnerable members of society find themselves. One social worker in this study explains that general rising levels of poverty have imposed changes on the nature of social work:

I think in terms of the level of poverty and deprivation that's increased quite significantly and that, obviously, has had an impact on the kind of work we're involved in. And I think certainly, sort of, at the latter end of the last ten years, things have become far worse than what they have ever been, so families are reaching us within Children and Family Service and now issues are far more entrenched (CL1, interview, 2018).

The poverty that the participant mentions cannot be thought of without considering the austerity measures that exacerbate the already dire situation for vulnerable members of society. Unleashed 
after the 'financial crisis' of 2007-2008, austerity measures were brought in by Conservative Chancellor George Osborne during the Conservative-Liberal Democrat coalition (2010-2015). The Child Poverty Action Group (CPAG) notes that Osborne "announced spending reductions of $£ 32$ billion a year by $2014 / 15$, of which $£ 21$ bn was to come from so-called 'welfare reform'. "Social security was a prime target of austerity, and the government presented existing levels of spending as 'unaffordable"” (Tucker, 2017: 8). In fact, CPAG continues, "cuts made between 2010 and 2015 remove around $f, 14.5$ billion a year from the social security budget, by both reducing the value of benefits and restricting entitlement...With pensioner benefits protected by the triple lock, the weight of these cuts has fallen heavily on working age people and families with children" (2017: 8), meaning that austerity is hitting hardest those who are already most vulnerable. The 'triple lock' refers to the UK government policy that "guarantees that the basic state pension will rise by a minimum of either $2.5 \%$, the rate of inflation or average earnings growth, whichever is largest" (Inman, 2017). For Ferguson and Lavalette, the cutting of services as part of the austerity agenda "reflects the determination of those who manage global capitalism that the costs of the crisis shall be paid by the mass of ordinary people who played no part in its creation" (Ferguson and Lavalette, 2013: 96).

For another participant, austerity has been a major change to social work. The participant comments that "we just feel that there are fewer options you can give people. We are going out there and asking them what they can do, rather than going out and offering services" (FG2, interview, 2018). Another respondent reflects that cuts have affected social work practice but that social workers are trying to "make the best of the resources we have got and we are very creative" (AH1, interview, 2018). This fits with existing research by Ferguson and Lavalette (2013) that sees the pernicious effects of the politico-economic austerity agenda on social work. While austerity hits hardest those most vulnerable in society, social workersare thwarted in their quests because of cuts to social services. One way in which this occurs is through the "imposition of 'higher eligibility criteria' in social care [which] is a polite way of saying that basic services that people require for a decent existence and to which they have been entitled for decades will no longer be available and that they will have to get by, somehow, without that support" (Ferguson and Lavalette, 2013: 96).

Perhaps more blatant than higher eligibility criteria are funding cuts and streamlining. One participant notes: 
I think the pressures, the cuts, local authority funding, is just a huge issue for social work across nationally...I think it's very sad, actually, how pressed we are in terms of budgets and I think that there is a risk that if we are squeezed any further that children will be placed at risk particularly in children's services in social work where this is no fat to trim...I think that we live in a world where you have to look at efficiency and streamlining and how do we get best value for money (LJ1, interview, 2018).

Another respondent in this study states that "we are now in a period where we have to kind of streamline our services and make sure that people we are actually supporting are the people that require it" (FG3, interview, 2018). A fellow participant adds that "it is a real balancing act having to look at the whole population and having to decide which groups need support and money really" (FG2, interview, 2018). Here, the impacts of austerity are clearly felt by participants, who recognise changes in their daily practice as a result of government measures.

\section{Technology as a form of managerialism}

External changes were not limited to poverty and austerity. Participants also reflected on the changes to the profession that have been enacted because of technological advances that hint at the rising tide of managerialism. Concerns have long been raised about the role of computers and information technology in social work. In his 1985 book, Computers in Social Work, Bryan Glastonbury (1985: 7) asks whether computers “will destroy the 'essence' of social work". and more recently, Garrett (2005) and Burton and van den Broek (2008) reflected that computers are becoming a central part of social work. One participant explains that technology, combined with cuts to administrative staff (in part because of technological developments) has turned social workers into administrators:

When I first started, we obviously didn't have computers. I remember writing all of my case notes and I also remember having an admin. There were four social workers who had an admin attached to them, and our admin worker typed up all of our children protection reports and our panel reports. So, we didn't do any of that admin side of things, which really allowed us to spend the majority of time with our families and that's a huge change. I think we are more IT literate and it is quicker to do things like that 
yourself but I think we have taken on a massive admin role as well as the social work role (AH1, interview, 2018).

This observation meets Glastonbury's anxieties regarding the impact of information technology on social work. He feared that while "computers could become a boon to the social worker...there is every risk that in the hands of insensitive political and managerial control they could add to the already high stressfulness of the task" (1985: 8). This reflects the neoliberal trend towards managerialism, which Harlow et al. (2012: 536) describe as being "a means of making material the ideology or discourse of neoliberalism". The managerial turn serves as an "apolitical mask" that disguises the political project of neoliberalism "carried out by the corporate capitalist class...[to] curb the power of labor" (Harvey, 2016). Managerialism presents under the supposedly benign guise of increased efficiency and technological change but, in fact, imposes business and administrative principles on a profession defined by its moral core.

Another participant affirms that technological advances have led to social workers becoming administrators butacknowledges that a benefit of technology is that "communication between people, including other disciplines, has probably improved through e-mail” (RK1, interview, 2018). This optimism is not widely-held, however, and another participant reflects that with technological advances has come a loss of in-person contact between social workers, which is detrimental to safety and morale (FG3, interview, 2018).

\section{The changing nature of social work}

While the previous section reflected on participants' comments related to the external changes that affected social work, this section touches on the perceived changes to the profession that either occurred internally or were directed singly at the social work profession. These changes affect the day-to-day reality of social work practice. Respondents note many changes to the field of social work that coalesce around the depoliticising of the social work identity and a change to the nature of practice through a shift away from relationships and processes towards outcome-based work that also focuses on the pathology rather than the systemic or structural nature of an individual's problems. The changes to social work that related directly to the profession also include integration and specialisation.

\section{Depoliticisation}


Participants observe that social work used to be inherently political, in line with the radical social work movement that emerged in the 1970s (Ferguson, 2009). One respondent in our study notes that "back in the 1980s, we were all quite political and we challenged all of the managers and we all stuck together" (FG2, interview, 2018), highlighting both the sense of camaraderie within the profession and the political roots of the field. Another respondent adds that "I think when I qualified...newly qualified social workers really saw themselves as challenging the system" (SM1, interview, 2018). This internal politicisation of the profession by social workers themselves is tied to the profession's foundational values of social justice and empowerment (BASW, 2014). One respondent further explicates the interweaving of politics and social work values, first explaining previously the field "was very much driven by your value base, and what brought people into the profession was about having a belief or having something you wanted to promote which would lead to better equality or better services" (FG2, interview, 2018). The respondent continues that "I don't see that in students that I work with these days", suggesting that this internal politicisation of the profession has changed over time, becoming less 'radical' (Ferguson and Lavalette, 2013).

This depoliticisation is no coincidence; it is part of successive neoliberal government attempts to manage and recraft social work training through the Thatcher government's Diploma in Social Work and the Blair government's BA Social Work. These programmes have been criticised by Rogowski for producing "predictable, reliable and compliant rather than fully fledged (semi)autonomous professionals" (Rogowski, 2015: 56) who are not grounded in the critical, radical values that are at the heart of social work. This government reshaping of social work training has attempted to erode the values from the core of social work through a bureaucratisation of social work training while simultaneously creating ever-more perilous social conditions for service users in which social workers would need to intervene.

\section{Individualising, pathologising and moralising}

The reasons for this transformation seemingly connect to a larger ideological shift, which another respondent discusses:

I think when I came into social work in the 70 s, we were very political and very much about social change and about mobilising people through group work and, you know, there was [sic] a lot of projects in the community that gathered people together. It was less emphasis on the individual being at fault for their problems, 
which is, I think, what happened in the 80 s with Thatcherism and things (FG1, interview, 2018).

Here, the participant notes not only that social work has become less political, but also that there has been a shift in the ideological assumptions underlying the field that connects with a larger political agenda, which will be discussed in more detail in the next section. For this respondent, there has been a distinct shift away from concern with structural or systemic issues in society that impact on the lives of individuals to a pathologising and moralising focus on the individual being responsible for his/her actions without concern for the wider structural causes.

This shift has impacted the type of work undertaken by social workers on a daily basis; one respondent notes that preventative community work, such as that based at family centres, has been cut (LJ1, interview, 2018) with a renewed focus on a 'fighting fires approach' that deals only with crises relating to the individual rather than the wider structural causes of the problems. Another participant affirms this, adding that "dealing with crisis after crisis, you are not actually dealing with any of the issues behind some of the behaviours and feelings that people are experiencing" (FG2, interview, 2018).

\section{From processes to outcomes}

In addition to the ideological shift that transitioned social work's focus from social, political and economic structures to a pathological view of the individual, which demonises poverty, the profession has seen a transition from a process-based approach that stresses the importance of relationships to an outcome-based approach that values high levels of efficiency with reduced government expenditure. This outcome-oriented approach, which serves as a political tool for measuring and monitoring to whom services are being directed and the efficacy of interventions, is contrary to the relationship-based work that practitioners laud.

The shift to the outcome-oriented approach was sudden and imposed top-down within the profession with little input from social workers on the ground. One respondent explains:

We became outcome-focussed and I was struck by the fact that the whole profession just suddenly goes, 'oh yeah, we're outcomefocussed now'. There was no debate or anything about it or anything; it seemed to be that the Scottish Government said, 'you 
guys are now outcome-focussed' and we all go, 'ok, fine' and that was it (MH1, interview, 2018).

This comment highlights key aspect of the neoliberal agenda: it is electively imposed by governments for the benefit of dominant bodies. The switch to measuring outcomes as the marker for 'successful' social work is problematic, however. Continuing the observation, the respondent notes that often it can take many years to see the effects of an intervention, thus rendering measuring outcomes very difficult (MH1, interview, 2018). For another respondent, this requirement to measure outcomes led to some unethical practices. The respondent describes how, during a particular case:

I got a phone call from a team leader...saying, 'well, you know how it is...' and they were describing the outcome that they wanted in this case, which they shouldn't have been doing at all and I was absolutely horrified (JB1, interview, 2018).

In this instance, practice was geared towards a certain outcome with little regard for the process and its organic development. The horror felt by the participant stems from the favoured processoriented approach that stresses the importance and primacy of relationships, and the therapeutic benefit of the process of intervention, which is, arguably, far more difficult to measure. One respondent sums up the importance of relationships, stating that "that's what social work is all about; it's about relationships" (LJ1, interview, 2018).

A fellow graduate affirms that training was structured around the importance of fostering relationships, adding that, "when I first started, the whole emphasis was on relationship building and that was really important, and I think we've lost that a little bit" (AH1, interview, 2018). However, practitioners reflect that relationship-building still remains central to their practice, despite externally-imposed government cuts, explaining that "we do that [build relationships] without a great deal of resources" (AH1, interview, 2018).

\section{The integration agenda and specialisation}

Alongside the ideological shift away from the primacy of relationships, sits the restructuring of the profession through the integration agenda that has seen social care married with health care, affecting practice. The Children's Act of 1995 also led to a restructuring of the field, as practitioners 
had to decide whether to specialise in child or adult service provision. One participant explains the benefits of specialisation, noting that, "through the split, there has been a greater sense of identity and confidence within the profession, and not feeling like you've just got to know such a wide range of information" (RK1, interview, 2018). This positive feeling is echoed by another participant who adds that, "I think with childcare, it's more about shared responsibilities, much more about you all having a part to play and actually also accepting your own limitations" (FG1, interview, 2018). Here, the participant is reflecting on the multi-agency and multi-party approach that has arisen because of specialisation. Embracing this multi-party approach with greater indepth subject knowledge, another participant adds that in relation to work with children, "you are getting a much more holistic sense of the child and how to meet their needs" (RK1, interview, 2018). Negative aspects of specialisation, however, are that "it can create fractions. This can distract from the focus on the child and, in some cases, can cause delay" (FG1, interview, 2018). Specialisation has also not, historically, been favoured; rather it was seen as preferable "that people actually get an opportunity to see broader aspects of social work" (SM1, interview, 2018).

Just as opinion of specialisation is mixed, with some arguing that it is divisive and others maintaining that it leads to enhanced practice, so, too, are opinions regarding the integration agenda. The integration of health and social care in Scotland can be traced back to the 1999 Joint Future Group that sought a level of integrated care as part of a larger 'modernisation' agenda, consistent with the newly devolved Scottish Executive's aims for community care (Burgess, 2016). One of integration's most recent manifestations is through Scotland's Health and Social Care Partnerships, implemented in 2016. One participant in this study maintains a positive vision of the increasing integration between health care and social care, explaining that, "it's about appreciating the differences and the differing roles but actually also being comfortable with the things that overlap between health and social work" (JM1, interview, 2018). While other participants also acknowledge that some good has arisen from the integration agenda, most describe the joining of health and social care — where social care is perceived as the 'junior partner' — with a tinge of regret. Through integration there has been "a real eradication of the role of social work" (FG3, interview, 2018) and social workers fear that "eventually the larger partner will take over" (MH1, interview, 2018). Another respondent explains that social workers struggle being managed by a person based in the health-system, feeling as if social work is being entirely subsumed by Health:

We feel like we're just kind of being rail-roaded into a way where the values and the way we were taught and trained to work is just 
being overrided [sic] by this massive organisation as in Health and it's frightening for people, and even for quite newly qualified social workers in my team, they're saying that as well because...that's not why they came into social work (FG3, interview, 2018).

Finally, one respondent reflects that integration is not working: "it's like putting a square peg into a round hole. You know, we just have completely different thinking” (FG3, interview, 2018).

\section{Connecting back: the neoliberalisation of social work}

The interviews with university graduates reveal some significant changes experienced in the profession and their responses connect to the larger debate about the neoliberalisation of social work discussed at the beginning of this paper. While the university has adapted to the changes through educational provision, the field of social work has changed significantly. Respondents note that theexperiences of social work practice have changed, and their responses point to larger, encompassing ideological shifts that have affected the field.

Such ideological shifts have clearly influenced the day-to-day experience of being a social worker. Poverty, deprivation and austerity have led to cuts that have impacted the services that social workers can provide, as previously noted by participants and discussed in this paper. However, the changes noted in the previous section (a shift to an outcome-focus, to specialisation, to integration, and to a concern with the individual rather than social structures) that have changed the experience of delivering social work, stem from a larger politico-economic and social ideological shift in society: the creeping intensification of neoliberalism and the external, top-down attempt to apply neoliberal principles to social work. Our findings correlate with Yuill's (2018) work that finds the social worker unable to enact his/her "compassionate self' and, instead, is mired in an outcome-oriented practice, with Fenton's (2014) determination that criminal justice social workers suffer "ethical stress", and with Garrett's (2009) assertion that neoliberalism has impacted social work practice through emphasis on private agencies.

The participants interviewed for this study largely concur with analyses that see a changing politics and explain how the larger ideological shifts affected their practice. Participants identified a neoliberal shift that seeks to make the social worker an agent of social control that manages andwhere necessary - punishes the vulnerable. This is exemplified in the creation of Youth Offending Teams (YOTs) in 1998. For Rogowski (2015: 57), the YOTs enshrined neoliberalism's punitive 
essence and they were ultimately responsible for the "criminalising of nuisance" : . For Fenton (2014), criminal justice social work that focuses on 'correcting' the individual without considering the broader context, amounts to a form of social control, which is far from the vision of an empowering social work based on concern for equality and human rights, in which respondents believe so passionately.

The funding of social work and the cuts that the profession has seen also hint at the rising tide of neoliberalism.

Cuts are central to the neoliberal agenda that sees government cut spending to reduce deficitsthis is clearest under the Conservative party's austerity policies that see services cut and resources diminish. However, public sector withdrawal was also seen under New Labour and, as such, the story of the current 'cuts' begins earlier. Under New Labour, there was a renewed focus on the use of third sector agencies and competitive tendering to deliver government policies (Haugh and Kitson, 2007; Morley et al., 2019: 39), thereby decreasing the role of the Keynesian welfare state. Participants note that, indeed, local authority social work is receiving increasingly high-tariff, "entrenched" cases that have been allocated to third sector agencies first (CL1, interview, 2018).

Streamlining is closely linked to cuts. Ferguson notes that efficiency, streamlining and managerialism go hand-in-hand, all to support the paring down of service provision and funding (2004). For Rogowski (2015: 58), “completing bureaucracy speedily so as to ration resources and assess/manage risk became the overriding goal" of New Labour's social work project. The Munro Review, driven in part by the high-profile death of Baby Peter in 2007, examined the levels of bureaucracy in the social work profession, finding that there was, in fact, too much bureaucracy faced by social workers and too little attention paid to the needs of the child (Rogowski, 2015: 59). Counterintuitively, however, Munro called for increased managerialism to combat this challenge (Rogowski, 2015: 59).

Our participants pointed to an issue that is an effect of streamlining and cuts: the re-emergence of the question of deserving and undeserving recipients of services and aid, which represents a broader theme in the neoliberalisation of society (Wacquant, 2009: xvii). In this way, poverty and vulnerability become subject to judgement and problematisation, connected with notions of crime and deviance (Hancock and Mooney, 2011) and morality. However, in constructing this vision of 
poverty, further cuts and streamlining are justified and normalised in an attempt to only help those who 'deserve' it.

Connected to this streamlining is New Labour's outcome-focus and integration projects that were part of the modernisation agenda: "the package of reforms on the New Labour agenda" (Midwinter, 2001: 311). For New Labour, 'modernisation' meant, in part, “a need to shift from a focus on inputs to a concern with outcomes” (Midwinter, 2001: 312). For Blair (2007 in Ferguson, 2014) himself, modernisation was concerned with creating "an economy fully attuned to a new global market", underscoring his concern for a neoliberal economy. Under New Labour came an increased concern for "partnership working" (Miller, 2010: 116) through a switch to an integration approach. This was, as previously discussed, picked up in newly-devolved Scotland and promoted, in part, through the Joint Future report and subsequent Joint Improvement Team (Miller, 2010: 120).

Creating an efficient economy that showed tangible and measurable results was part of this modernisation agenda and the outcome-focus in social work formed part of this. Outcome measures-performance measurement, metrics and indicators-can justify spending or withdrawal of funding and, returning to Ferguson's explanation, he reminds us that such a system "lends itself to behaviourist approaches which measure behavioural change and which usually have a strongly individualistic focus, with little concern for wider social factors" (Ferguson, 2014). This fits with the ideological shift that sees a pathologising of the individual and a disregard for societal and structural issues. Instead of engaging in preventative, community-based work, and instead of focusing on the therapeutic benefit of relationship formation, social work under a neoliberal regime seeks to move the focus away from process and need and, instead, orients towards outcomes, failing to focus on the primacy of relationships (AH1, interview, 2018).

\section{Conclusion}

This paper has engaged with current literature one the politicisation and neoliberalisation of social work but has supplemented traditional document and policy analysis with an argument based on changes perceived by social work graduates, most of whom are or have been practising social workers. We began by discussing the external changes that social workers have noticed are bearing down on their profession including austerity and technological changes. We then discussed the changes within and internal to the profession, highlighting the depoliticisation of the field, the shift to outcome-oriented practice, a pathological rather than structural approach, the integration of 
health and social care, and specialisation. All of these led to social workers feeling less engaged and less able to conduct their practice in the way that they would like and in the way that they were trained to do.

Social work graduates noted that their profession had changed significantly and we wove their stories in with the specificities of the neoliberalisation of the profession, showing that the changes noted by academics are being felt 'on the ground' by practitioners. Our study was retrospective, asking graduates to look back on changes that they had noted since beginning in practice, and the benefit of this approach is that we were able to capture perceived change over time. It would be advantageous to complete further research with service users who have been involved with social work for many years to gain an understanding of whether their experiences have changed in the face of the neoliberal onslaught or whether the changes to the profession remain invisible to service users.

Neoliberalism under the guise of Third Way politics and the Age of Austerity is antithetical to the values of social work and targets the profession's moral core (Morley et al., 2019: 36). Yet, even in this hostile environment, the social workers interviewed for this study remain optimistic about the profession and maintain an allegiance to its values in the face of the neoliberalising profession. They are operating in a system that does not support their values of equality, empowerment and social justice, and yet, with few resources available, they continue to offer support and guidance on a daily basis. They continue to build relationships with service users "and we do that without a great deal of resources", explains one participant (AH1, interview, 2018), thus highlighting the determination to adhere to social work's founding principles despite ideological shifts. Against a system that promotes increasing reliance on metrics and outcomes, one participant offers advice for daily practice in the context of creeping neoliberalism: "stick to your values. Challenge anything that goes against that" (SM1, interview, 2018).

\section{References}

Aadnanes, M. (2017). Social workers' challenges in the assessment of child abuse and maltreatment: intersections of class and ethnicity in child protection cases. Critical and Radical Social Work, 5(3), pp. 335-50.

Barton, H., Bell, K. and Bowles, W. (2005). Help or hindrance? Outcomes of social work student placements. Australian Social Work, 58(3), pp. 301-312.

BASW, (2018). Code of Ethics. [online] Available at: https://www.basw.co.uk/aboutbasw/code-ethics [Accessed 20 Nov. 2018]. 
Beatty, C. and Fothergill, S. (2013). Hitting the poorest places hardest: the local and regional impact of welfare reform. Sheffield: Centre for Regional Economic and Social Research.

Bruff, I. (2014). The rise of authoritarian neoliberalism. Rethinking Marxism, 26(1), pp.113-129.

Burgess, L. (2016). SPICe Briefing: Integration of Health and Social Care. Edinburgh: Scottish Parliament.

Burton, J. and Van den Broek, D. (2008). Accountable and countable: Information management systems and the bureaucratization of social work. British journal of social work, 39(7), pp.1326-1342.

Conservative Party (1976). The Right Approach. London: Conservative Party Central Office.

Davies, J.S. (2012). Active citizenship: navigating the Conservative heartlands of the New Labourproject. Policy \& Politics, 40(1), pp.3-19.

Department of Health (2000). Framework for the Assessment of Children in Need and their Families. Norwich: The Stationery Office Ltd.

Dorling, D., Rigby, J., Wheeler, B., Ballas, D., Thomas, B., Fahmy, E., Gordon, D. and Lupton, R. (2007). Poverty and wealth across Britain 1968 to 2005. Bristol: Policy Press.

Fenton, J. (2014). Can social work education meet the neoliberal challenge head on?. Critical and Radical Social Work, 2(3), pp.321-335.

Ferguson, I. (2004). Neoliberalism, the Third Way and Social Work: the UK Experience. Social Work and Society, 2(1).

Ferguson, I. (2009). Another Social Work is Possible! Reclaiming the Radical Tradition, in Leskosek, V. (ed.) Theories and Methods of Social Work: Exploring Different Perspectives. Ljubljana: University of Ljubljana, pp. 81-98.

Ferguson, I. and Woodward, R. (2009). Radical social work in practice: Making a difference. Bristol: Policy Press.

Ferguson, I. and Lavalette, M. (2013). Crisis, austerity and the future(s) of social work in the UK. Critical and Radical Social Work, 1(1), pp.95-110.

Garrett, P.M.(2003). Swimming with dolphins: The Assessment Framework, New Labour and new tools for social work with children and families. British Journal of Social Work, 33(4), pp.441-463.

Garrett, P.M. (2005). Social work's 'electronic turn': Notes on the deployment of information and communication technologies in social work with children and families. Critical Social Policy, 25(4), pp.529-553.

Garrett, P.M. (2010). Examining the 'conservative revolution': Neoliberalism and social work education. Social Work Education, 29(4), pp.340-355. 
Glastonbury, B. (1985). Computers in Social Work: Houndmills (UK): Macmillan.

Gold, T. (2011). "Problem Families" Do Not Need an Army of Hyacinth Buckets Shouting at Them'. The Guardian, 27 August, p. 39.

Hancock, L. and Mooney, G. (2011). 'Saints and scroungers': constructing the poverty and crime myth. Criminal Justice Matters, 83(1), pp.26-27.

Harlow, E., Berg, E., Barry, J. and Chandler, J. (2012). Neoliberalism, managerialism and the reconfiguring of social work in Sweden and the United Kingdom. Organization, 20(4), pp. 534-550.

Harvey, D. (2016). Neoliberalism is a political project. Jacobin, https://www.jacobinmag.com/2016/07/david-harvey-neoliberalism-capitalism-laborcrisis-resistance/

Haugh, H. and Kitson, M. (2007). The Third Way and the third sector: New Labour's economic policy and the social economy. Cambridge Journal of Economics, 31(6), pp.973-994.

Inman, P. (2017). 'Pensions triple lock: what you need to know'. The Guardian, 27 April. Online. Available at: https://www.theguardian.com/money/2017/apr/27/pensions-triple-lockquestions-answered [Accessed 16 July 2019].

Ishkanian, A. and Szreter, S. eds. (2012). The Big Society Debate: A New Agenda for Social Policy? Cheltenham (UK): Edward Elgar Publishing.

Jones, R. (2017). Politicians are stealthily trying to take control of social work. The Guardian, 7 April. Online. Available at: https://www.theguardian.com/social-carenetwork/2017/apr/07/politicians-are-stealthily-trying-to-take-control-of-social-work [Accessed: 22 January 2019].

Levitas, R. (2012). The just's umbrella: Austerity and the big society in coalition policy and beyond. Critical Social Policy, 32(3), pp.320-342.

Lymberry, M. (2005). Social Work with Older People. London: SAGE.

Midwinter, A. (2001). New Labour and the Modernisation of British Local Government: A Critique. Financial Accountability and Management, 17(4), pp.311-320.

Miller, E. (2010). Can the shift from needs-led to outcomes-focused assessment in health and social care deliver on policy priorities? Research, Policy and Planning, 28(2), pp.115-127.

Morley, C., Ablett, P. and Macfarlane, S. (2019). Engaging with Social Work. Cambridge: Cambridge University Press.

Mudge, S.L. (2008). What is neo-liberalism?. Socio-economic review, 6(4), pp.703-731.

O'Conner, J. (2010). Marxism and the three movements of neoliberalism. Critical Sociology, 36(5), pp. 691-715.

Social Work at Edinburgh University. (2018). Social Work Centenary: Celebrating 100 years of Social 
Work at Edinburgh University : Celebrating 100 years of Social Work at Edinburgh University. [online] Available at: http://www.socialwork.ed.ac.uk/centenary [Accessed 22 Jan. 2019].

Spolander, G., Engelbrecht, L., Martin, L., Strydom, M., Pervova, I., Marjanen, P., Tani, P., Sicora, A. and Adaikalam, F. (2014). The implications of neoliberalism for social work: Reflections from a six-country international research collaboration. International Social Work, 57(4), pp.301-312.

Rogowski, S. (2015). Margaret Thatcher's legacy for social work with children and families: critical possibilities?. Critical and Radical Social Work, 3(1), pp.53-65.

Tucker, J. (2017). The Austerity Generation: the impact of a decade of cuts on family incomes and child poverty. London: Child Poverty Action Group.

Turbett, C. (2018). Community social work in Scotland: a critical history. Glasgow: IRISS.

Wacquant, L. (2009). Punishing the poor. Durham, NC: Duke University Press.

Yuill, C. (2018). Social workers and alienation: the compassionate self and the disappointed juggler. Critical and Radical Social Work, 6(3), pp. 275-289. 